\title{
Restorative Justice and the South African Truth and Reconciliation Process ${ }^{1}$
}

\author{
Christian B.N. Gade \\ Department of Culture and Society \\ Aarhus University \\ Jens Chr. Skous Vej 7 \\ 8000 Aarhus C \\ Denmark \\ christianbngade@gmail.com
}

\begin{abstract}
It has frequently been argued that the post-apartheid Truth and Reconciliation Commission (TRC) was committed to restorative justice $(\mathrm{RJ})$, and that RJ has deep historical roots in African indigenous cultures by virtue of its congruence both with ubuntu and with African indigenous justice systems (AIJS). In this article, I look into the question of what RJ is. I also present the finding that the term 'restorative justice' appears only in transcripts of three public TRC hearings, and the hypothesis that the TRC first really began to take notice of the term 'restorative justice' after April 1997, when the South African Law Commission published an Issue Paper dealing with RJ. Furthermore, I show that neither the connection between RJ and ubuntu nor the connection between RJ and AIJS is as straightforward and unproblematic as often assumed.
\end{abstract}

\section{Introduction}

In my research on $u b u n t u$ and the South African transition from apartheid to multi-racial democracy (see Gade 2011 \& Gade 2012), I have frequently come across references to restorative justice (RJ). This is what has inspired me to look deeper into the issue of RJ and the South African truth and reconciliation process in this article.

I will begin by exemplifying the idea that whereas the post-apartheid Truth and Reconciliation Commission (TRC) did not offer retributive justice, it did promote another kind of justice, namely RJ. Afterwards, I want to look deeper into the question of what $\mathrm{RJ}$ is. It seems generally accepted in the present literature on RJ that the term 'restorative justice' was coined during the second half of the twentieth century. However, I will show that the term has appeared in written sources since at least 1834. Furthermore, I will argue that it might be reasonable to consider the so-called RJ movement a post-1990 phenomenon, even though many of the ideas most central to this movement were already put on the criminal justice agenda by scholars such as Albert Eglash, Nils

1 A draft version of this article was presented at the conference 'Conceptions of Justice', Aarhus, 28 June 2012. I want to thank all those who were present for their comments. Furthermore, I want to direct special thanks to Steen Wackerhausen, Aase Rieck Sørensen, Birgitte B.N. Gade and Lucy Seton-Watson. I am particularly grateful for your guidance and comments. 
Christie, Randy Barnett and Howard Zehr during the period 1950-1990. I will also explain that today, the term 'restorative justice' is used by so many different people, in so many different contexts and for so many different purposes, that the meaning of the term has become quite vague. There is no agreement on what RJ is.

The next thing I will do is return to the issue of RJ and the South African truth and reconciliation process. Firstly, I will present the finding that the term 'restorative justice' appears only in the transcripts of three public TRC hearings (one victim hearing and two special hearings), whereupon I will explore the use of the term 'restorative justice' in the Truth and Reconciliation of South Africa Report (hereafter 'the TRC Report' or simply 'the Report'). The understanding of RJ in the TRC Report is inspired by the understanding of RJ in Issue Paper 7, published by the South African Law Commission in April 1997. It is my hypothesis that the TRC first really began to take notice of the term 'restorative justice' after the publication of this Issue Paper. If this is true, then it does, to a considerable extent, represent a retrospective self-interpretation when the Report describes the TRC as an institution committed to RJ.

In the last part of the article, I will show that in post-apartheid South Africa, a number of people have argued that RJ has deep historical roots in African indigenous cultures by being congruent with ubuntu and African indigenous justice systems (AIJS). This needs to be understood within the context of the call for an African renaissance in post-apartheid South Africa, and the call for Africanization in post-colonial Africa more generally. If it could be shown that RJ has deep historical roots in African cultures, then this would have legitimizing effects on RJ among people who are calling for Africanization. I will argue that both the connection between RJ and $u b u n t u$ and that between RJ and AIJS are less straightforward and unproblematic than often assumed. Firstly, the idea that RJ is congruent with ubuntu seems to have been formulated in writing for the first time in history in the second half of the 1990s, and there is no consensus on how the connection between RJ and ubuntu is constituted. This may not come as a surprise, for not only is there no consensus on what RJ is, there is also no consensus on the nature of ubuntu (Gade 2011 \& Gade 2012). Secondly, according to written sources from the nineteenth and the first half of the twentieth century, AIJS of former times were not as restorative as is often assumed at present, a finding that might suggest that the idea of harmony between RJ and AIJS lacks nuances. Accord-

ing to some sources on AIJS, witchcraft, murder, theft and incest were sometimes punished by death.

After these words of introduction, I will now turn to exemplify the idea that whereas the post-apartheid TRC did not offer retributive justice, it did promote another kind of justice, namely RJ.

\section{Dealing with the Past in Post-Apartheid South Africa: The Question of Justice}

In the TRC process, apartheid perpetrators were offered conditional amnesty. They had to file an individual amnesty application and show that the gross violations of human rights for which they sought amnesty were politically motivated. Furthermore, they had to disclose the full truth about their violations, normally during public hearings (the conditions for amnesty are formulated in detail in Chapter 4 of the Promotion of National Unity and Reconciliation Act, No. 34 of 1995). The TRC received 7,112 amnesty applications and granted amnesty to 849 perpetrators. 
Was justice sacrificed when the TRC offered conditional amnesty to perpetrators? According to Desmond Tutu, the chairman of the TRC, the correct answer to this question is in the negative. In the foreword of the TRC Report, he explains that:

Those who have cared about the future of our country have been worried that the amnesty provision might, amongst other things, encourage impunity because it seemed to sacrifice justice. We believe this view to be incorrect. The amnesty applicant has to admit responsibility for the act for which amnesty is being sought, thus dealing with the matter of impunity. Furthermore, apart from the most exceptional circumstances, the application is dealt with in a public hearing. The applicant must therefore make his admission in the full glare of publicity. Let us imagine what this means. Often this is the first time that an applicant's family and community learn that an apparently decent man was, for instance, a callous torturer or a member of a ruthless death squad that assassinated many opponents of the previous regime. There is, therefore, a price to be paid (TRC Report 1998, Vol. 1: 8).

Though it was not cost-free for perpetrators to take part in the amnesty process, the TRC clearly did not offer retributive justice since it did not impose punishment on perpetrators. On the contrary, the TRC did, by means of amnesty, ensure that some perpetrators could not be punished for the human rights violations they had committed. If the TRC offered justice, then it must be another kind of justice which is not retributive in nature. Desmond Tutu explains that such a kind of justice exists, and that it is served when efforts are being made to work for healing, for forgiveness and for reconciliation (note the references to ubuntu and African jurisprudence below):

Retributive justice - in which an impersonal state hands down punishment with little consideration for victims and hardly any for perpetrators - is not the only form of justice. I contend that there is another kind of justice, restorative justice, which was characteristic of traditional African jurisprudence. Here the central concern is not retribution or punishment but, in the spirit of ubuntu, the healing of breaches, the redressing of imbalances, the restoration of broken relationships. This kind of justice seeks to rehabilitate both the victim and the perpetrator, who should be given the opportunity to be reintegrated into the community he or she has injured by his or her offence. This is a far more personal approach, which sees the offence as something that has happened to people and whose consequence is a rupture in relationships. Thus we should claim that justice, restorative justice, is being served when efforts are being made to work for healing, for forgiveness and for reconciliation (Tutu 1999: 51).

In the literature on the $\mathrm{TRC}$, the work of the Commission is commonly held to be congruent with RJ. Richard Bell explains that: 'It is in the correlation between ubuntu, rooted in whatever forms of "communalism" may survive in South Africa (moderate or otherwise), and the kind of justice referred to as "restorative justice", that we find the foundation stones for the Truth and Reconciliation Commission and a possibility for a moral and spiritual renaissance' (Bell 2002: 90). Alex Boraine also writes that '[r] estorative justice has manifested itself in the concept of a truth commission and in the South African model in particular' (Boraine 2000: 426). Furthermore, Ann Skelton and Cheryl Frank refer to the TRC as 'South Africa's most famous and engaging experience with restorative justice' (Skelton \& Frank 2001: 116). It has, however, also 
been argued that the mandate of the TRC was not fully in harmony with RJ. In the section of the TRC Report entitled 'Ubuntu: Promoting Restorative Justice' (TRC Report 1998, Vol. 1: 125-131), the Commission describes itself as an institution that attempts to promote RJ, but it also notes that:

Restorative justice demands that the accountability of perpetrators be extended to making a contribution to the restoration of the well-being of their victims. Although neither the interim Constitution nor the Act [the Promotion of National Unity and Reconciliation Act, No. 34 of 1995] provides for this, this important consideration was highlighted by the Commission. The fact that people are given their freedom without taking responsibility for some form of restitution remains a major problem with the amnesty process. Only if the emerging truth unleashes a social dynamic that includes redressing the suffering of victims will it meet the ideal of restorative justice (TRC Report 1998, Vol. 1: 131).

Sometimes perpetrators did offer restitution after they had received amnesty. Khoza Mgojo, one of the former TRC commissioners, gave a good example during an interview I conducted with him in 2008. He told me about Brian Mitchell, who was granted amnesty for his role in killing 11 people in the 1988 Trust Feed Massacre. After amnesty had been granted, Khoza Mgojo led a group that set up a meeting in Trust Feed between Brian Mitchell and the people affected by the killings:

It was tense! The police had to be there because we did not know what was going to happen. We were just taking the chance. When Brian Mitchell told his story the people were fuming with anger, but at the end of it all the people thanked Brian Mitchell for his courage to come and face them. That is where the relationship started between Brian Mitchell and the community. Mitchell promised that he was going to help them by supporting the community, by raising funds somewhere so that maybe a centre for the community could be established. And then the friendship began [which has lasted] up to now. So that is why I say that if people who have done something, if they give back to the people they have injured [i.e. offer restitution], it helps - I saw it with Brian Mitchell (interview in Gamalakhe on 17 November 2008).

\section{Restorative Justice}

So far I have not gone into much detail with the nature of RJ. I intend to make up for this in the present section. I will begin by exploring the genealogy of the term 'restorative justice', before I look into the nature of the so-called RJ movement and the definition of RJ.

The Genealogy of the Term 'Restorative Justice'

Christopher Marshall writes that the 'term restorative justice was coined in the 1970s to describe a way to respond to crime that focuses primarily on repairing the damage caused by the criminal act and restoring, insofar as possible, the dignity and wellbeing of all those involved' (Marshall 2011: dictionary entry 'Justice, Restorative'). In 1993, Daniel W. Van Ness was more concrete in terms of genealogy and stated that the term 'restorative justice' was probably coined by Albert Eglash in 'Beyond Restitution: Creative Restitution', published in 1977 (Van Ness 1993: 258). The idea that Albert Eglash coined the term 'restorative justice' has been widespread in the literature since it was introduced by Daniel W. Van Ness in 1993 (see e.g. Llewellyn \& Howse 1999: 
4; Ammar 2003: 149; Chatterjee \& Elliott 2003: 348; Heath-Thornton 2009: 228; Van Ness \& Strong 2010: 21; Daly 2013: 358).

It seems to be generally accepted that the term 'restorative justice' was coined during the second half of the twentieth century. Nevertheless, this idea does not reflect the truth. By means of the advanced search functions in Google Books, I have been able to locate the term in six texts from the pre- 1950 period. These are:

- The Christian Examiner and Church of Ireland Magazine from 1834, where it is explained that a certain Title Composition Act was 'deservedly hailed by all well-thinking men, as beneficial to the clergy, and to the people, as a great act of restorative justice' (Members of the Church of Ireland 1834: 2).

- The Signs of the Times from 1848. In this book, Lebbeus Armstrong tells a story about two witnesses who had been unjustly imprisoned for committing perjury and states that 'their release would be an act of restorative justice' (Armstrong 1848: 275).

- John Stow's Thoughts on a Continuation of the Book of Common Prayer used in the Church of England from 1856. As a comment to Luke 19:8, where Zacchaeus tells Jesus of Nazareth that he will give half of his possessions to the poor and pay back fourfold if he has cheated anyone of anything, John Show writes: 'What a lesson of liberality and of restorative justice is here afforded to All, who profess faith in CHRIST and the adoption of the Tenets of His Gospel!' (Stow 1856: 54).

- Burton Abbot's A Woman's Story from 1863. In this book, Cecil decides to give Salome a considerable amount of money which she, apparently, had been entitled to since childhood. It is explained that 'Cecil represented the case merely as an act of restorative justice' (Abbots 1863: 338).

- Floyd R. Mechem's article 'An Inquiry Concerning Justice' from 1916. This text contains an explicit definition of 'restorative justice' as 'justice administered by the judicial machinery which restores man to his proper rights' (Mechem 1916: 361).

- A speech by Manuel Fourcade from 1924, in which he addresses the problems of peace after World War I. He claims that in biblical times, the enthusiasm of the Psalmist exalted itself in a vision of justice embracing peace and states that '[i]t is fitting to reaffirm our belief in these ideas of restorative justice' (Fourcade 1924: 768).

What is meant by 'restorative justice' in the texts from the pre-1950 period? In the four nineteenth-century texts, the term is used without its meaning being explained. Taking the contexts where the term appears into consideration, it is plausible that the authors of the four texts simply understood an act of RJ as an act that restores, or aim to restore, a state of justice. Nevertheless, other interpretations might be possible. There are also uncertainties with respect to the exact meaning of the term 'restorative justice' in the two texts that I have quoted from the twentieth century. Floyd R. Mechem does not explain what rights his definition of 'restorative justice' refers to, and it is unclear precisely what ideas Manuel Fourcade has in mind when referring to 'these ideas of restorative justice'.

Despite such uncertainties concerning the meaning of the term 'restorative justice' in the pre-1950 texts, I believe I am justified in claiming this much: the meanings that are ascribed to the term 'restorative justice' in the present, so-called RJ movement 
have been influenced by texts published since 1950, and nothing suggests that these meanings can be fully reduced to the meanings that were ascribed to the term in the pre-1950 period. But to what extent are there similarities between the meanings that are ascribed to the term 'restorative justice' in texts from before 1950 and the meanings ascribed to the term in the RJ movement at present? Have the former somehow influenced the latter? I will leave these questions for other scholars to investigate.

The Restorative Justice Movement: Some Core Ideas

To my knowledge, there were no written references to a 'restorative justice movement' prior to the $1990 \mathrm{~s}$. In recent years, however, a large number of authors have been writing about such a movement (to mention a few: Strickland 2004: 3; Johnstone 2008: 59; Leonhard \& Kenny 2010: 99; Armour \& Umbreit 2011: 392). It might be reasonable to consider the RJ movement as a post-1990 phenomenon, both because the idea of the existence of such a movement does not seem to have been articulated prior to the 1990s, and because the term 'restorative justice' did not gain widespread international popularity before the 1990s. However, many of the ideas that are most central to the RJ movement had already been put on the criminal justice agenda by scholars such as Albert Eglash, Nils Christie, Randy Barnett and Howard Zehr during the period 1950-1990. Below I want to describe four of these ideas:

(I) The idea that the perpetrator should offer restitution to the victim. Albert Eglash was very influential in putting the issue of restitution on the criminal justice agenda during the second half of the twentieth century. His articles on restitution include 'Creative Restitution: A Broader Meaning for an Old Term' (Eglash 1957a), 'Creative Restitution: Some Suggestions for Prison Rehabilitation Programs’ (Eglash 1957b), 'Creative Restitution: Its Roots in Psychiatry, Religion and Law' (Eglash 1959) and 'Beyond Restitution: Creative Restitution' (Eglash 1977). Albert Eglash claims that when he began to write on restitution in the 1950s, the term 'restitution' was only used to refer to money (Eglash 1957a: 619). The kind of creative restitution that he suggested should be part of the criminal justice process may consist in many different things. If a car thief, for instance, decides to wash his victim's car every Sunday for a month, doing so could be a form of restitution (Eglash 1957a: 620). Albert Eglash explains that '[i]n creative restitution, an offender, under appropriate supervision, is helped to find a way to make amends to those he has hurt, making good the damage or harm he has caused, and going a second mile whenever possible, e.g. by going beyond simple repair, by offering restitution despite punishment, or helping others like himself' (Eglash 1959: 117). Albert Eglash's thinking about restitution has influenced many contemporary RJ scholars. However, the term 'restorative justice' did not play any significant part in his early authorship. The first text where Albert Eglash makes a clear link between his own concept of creative restitution and RJ is 'Beyond Restitution: Creative Restitution' from 1977, where he explains that just as retributive justice has 'its technique of punishment for crime', RJ has 'its technique of restitution' (Eglash 1977: 91).

(II) The idea that the criminal justice process should include the active participation of all affected parties. Nils Christie highlighted this idea in his famous 1977 article, 'Conflict as Property'. According to Nils Christie's analysis, the present criminal justice systems in Western societies are problematic because they steal conflicts from their rightful owners: the neighbourhoods. Inspired by a community court case in the Arusha province of Tanzania, Nils Christie suggested that Western criminal courts should be replaced by victim-oriented courts that bring together the victim, the of- 
fender and the broader neighbourhood. The court should follow a four-stage process (Christie 1977: 10). In the first stage, it should be established whether it is true that a particular person has broken the law. In the second stage, it should be considered what could be done for the victim, particularly by the offender, but also by the local neighbourhood and the state. In the third phase, there should be a decision on punishment, understood as that suffering which the court may find necessary to apply in addition to the (assumed) constructive suffering that the offender would go through in his restitutive actions towards the victim. Finally, the fourth phase should concern service to the offender who might be in need of various kinds of support. Nils Christie's call for inclusive criminal justice processes that involve direct encounters between victims and offenders has likewise inspired many contemporary RJ scholars. However, to my knowledge, it was not until the 2000s that the term 'restorative justice' began to play some part in his writings (see e.g Christie 2005; Christie 2010).

(III) The idea that the criminal justice paradigm of punishment/retribution is in crisis. Randy Barnett highlighted this idea in 'Restitution: A New Paradigm of Criminal Justice' (1977) and suggested that restitution should be introduced as a new paradigm. However, the term 'restorative justice' did not appear in his article. In 1985, Howard Zehr published an article entitled 'Retributive Justice, Restorative Justice' which was explicitly inspired by Barnett 1977. In this article, Howard Zehr agrees with Randy Barnett that the existing criminal justice paradigm is in crisis, but he does not follow him in pointing to restitution as a new paradigm. Instead, he suggests that RJ should be a new paradigm of criminal justice. This suggestion was later unfolded and nuanced in Changing Lenses: A New Focus for Crime and Justice (Zehr 1990) and The Little Book of Restorative Justice (Zehr 2002). In 'Retributive Justice, Restorative Justice', Howard Zehr emphasizes that the paradigm of RJ is radically different from the paradigm of retributive justice. For one, the paradigm on retributive justice perceives crime as a conflict between individual and state, whereas the paradigm of RJ considers crime as a conflict between individuals. Howard Zehr explains that the paradigm of RJ supports dialogue and that '[i]t encourages victim and offender to see one another as persons, to establish or re-establish a relationship' (Zehr 1985: no page number).

(IV) The idea that RJ has been the dominating form of criminal justice for most of human existence. This idea was already formulated by Howard Zehr in 'Retributive Justice, Restorative Justice' in 1985. Here Howard Zehr emphasizes that retributive justice has only been the dominating criminal justice paradigm in recent centuries. $\mathrm{He}$ adds: 'It is difficult to realize sometimes that the paradigm which we consider so natural, so logical, has in fact governed our understanding of crime and justice only for a few centuries' (Zehr 1985: no page number). The idea that RJ has roots that extend far back in history has been repeated by many contemporary RJ scholars. John Braithwaite is, for instance, frequently quoted for the claim that ' $r$ restorative justice has been the dominant model of criminal justice throughout most of human history for all the world's people' (Braithwaite 1998: 323). Similarly, Elmar G.M. Weitekamp states that 'humans have used forms of restorative justice for the larger part of their existence' (Weitekamp 1999: 97).

The Restorative Justice Movement: Popularity, Expansion and Vagueness

Kathleen Daly writes that '[d]uring the 1900 s, restorative justice became immensely popular, eclipsing and overtaking other justice ideas circulating during the 1970s and $1980 \mathrm{~s}$ - a range of restitution, reparation, reconciliation, and informal justice projects' 
(Daly 2013: 357). RJ has even been supported by the UN. In 2002, the United Nations Economic and Social Council endorsed the United Nations Basic Principles on the Use of Restorative Justice Programmes in Criminal Matter. The UN states that: 'Member States should consider the formulation of national strategies and policies aimed at the development of restorative justice and at the promotion of a culture favourable to the use of restorative justice among law enforcement, judicial and social authorities as well as local communities' (quoted in United Nations Office of Drugs and Crime 2006: 102).

A still growing number of ideas have been connected to the term 'restorative justice', which is partly due to the fact that the term has been used in an increasing number of diverse contexts. When the term appeared in the writings of scholars such as Albert Eglash and Howard Zehr prior to the 1990s, it was explicitly within the context of criminal justice. In this context, RJ was presented as something that could provide a better alternative to existing, retributive criminal justice systems. Since the 1990s, the term 'restorative justice' has entered new arenas. The term has, for instance, been used in relation to many different sorts of behaviour that while meeting with disapproval do not constitute crimes: "This "downward expansion" includes misconduct in schools and children's residential care, inappropriate behaviour in the workplace, elder abuse, child protection issues and neighbourhood disputes' (Groothues 2012: 22). Furthermore, the term has also entered contexts of mass violence and group conflicts: 'As well as shifting its focus "downwards" from crime, the campaign for restorative justice has also looked "upwards" from "ordinary" crime to problems involving genocide, gross violations of human rights and political oppression' (Groothues 2012: 23).

Today, the term 'restorative justice' is used by so many different people, in so many different contexts and for so many different purposes that the meaning of the term has become quite vague. The members of the so-called RJ movement are not bound together by a shared definition of 'restorative justice'. So what makes the RJ movement a movement? And exactly who are the people who constitute this movement? These questions are difficult to answer. It might be argued that the RJ movement consists of people who share ideas such as those four that I have listed above. But what ideas, if any, does a person necessarily have to share to be part of the RJ movement? Is the sharing of specific ideas a sufficient condition for being part of this movement? Could it be that the term 'movement' suggests a unity that is non-existent? And do RJ practitioners in general consider themselves to be part of a movement? I do not think that such questions have been sufficiently dealt with in the current literature.

\section{Common Ideas about the Nature of RJ}

The literature contains a number of different ideas about what RJ is. It has, for instance, been argued that RJ is a way of thinking and behaving (Allena 2004: 57), and that it is a kind of talking therapy (Zedner 2006: 171). However, even though there is no universally shared definition of RJ, at least two ideas about its nature have been very common since the 1990 s. The first of these ideas is that RJ is a process. I will quote a few texts where this idea occurs:

- $\quad$ 'Restorative justice is a process whereby all the parties with a stake in a particular offence come together to resolve collectively how to deal with the aftermath of the offence and its implications for the future' (Marshall 1996: 37; Marshall 1999: 5). 
- 'Restorative justice is a process to involve, to the extent possible, those who have a stake in a specific offense and to collectively identify and address harms, needs, and obligations, in order to heal and put things as right as possible' (Zehr 2002: $37)$.

- 'The most general meaning of restorative justice is a process where stakeholders affected by an injustice have an opportunity to communicate about the consequences of the injustice and what is to be done to right the wrong' (Braithwaite \& Strang 2002: 4).

- 'Restorative justice is a process designed to bring out the best in the offender instead of becoming isolated and embittered, being grateful for fair treatment and in the victim - instead of seeking revenge, accepting the offender's apology and/or restitution' (Van Wormer 2003: 448).

- 'Restorative justice is a process of bringing together all the stakeholders (offenders, victims, communities) in pursuit of a justice that heals the hurt of crime, instead of responding to the hurt of the crime by using punishment to hurt the offender' (Dorpat 2007: 236).

It has also been a very common idea that RJ is a theory. Understood as a theory, RJ is not itself a process, but rather something that may inform or underpin processes, such as those described above. A few quotes for exemplification:

- 'Restorative justice is a theory of justice that emphasizes repairing the harm caused or revealed by criminal behaviour. It is best accomplished through inclusive and cooperative processes' (Van Ness 2005: 3).

- 'Restorative justice is a theory of justice that emphasizes repairing the harm caused by criminal behaviour. Restoration means bringing back or reinstating a right, a practice, or a situation. It is best accomplished through cooperative processes that include all stakeholders' (Burkhead 2009: 116).

- ' $[R]$ estorative justice is a theory that believes that instead of society punishing criminals by putting them in prison, they [the criminals] should be given the chance to correct the wrong they have done. Once criminals have done this, they can be brought back into society. The victim plays a large part in the process and may receive some type of restitution from the offender' (Pressler, Saner \& Wasserfall 2009: 28).

- 'Restorative justice is a theory of justice that engages those that are harmed and the wrongdoers (and the community, where applicable) "in search for solutions that promote repair, reconciliation, and the rebuilding of relationships" (Olson-Burchanan \& Boswell 2009: 168).

- 'Restorative justice is a theory of justice that is proactive rather than reactive. It tries to deconstruct the idea of retribution by recognising the need for community healing; so, it evaluates the hurts in terms of the values of the economic and social justice perspectives that community must adopt in order to obtain the best possibility of preventing future crime' (Stamatakis \& Vander Beken 2010: 289). 


\section{The Term 'Restorative Justice' in the Public TRC Hearings and the TRC Report}

Having cast some light on the complexity of the issue of RJ, I will now return to the South African truth and reconciliation process. As explained above, the work of the TRC is commonly held to be congruent with RJ. Nevertheless, I have not been able to find any texts that explore the extent to which the term 'restorative justice' appeared during the public TRC hearings. In this section, I will embark on such an exploration, and I will also examine what the TRC Report has to say about RJ.

\section{The Term 'Restorative Justice' in the Public TRC Hearings}

The TRC held public victim hearings from April 1996 to June 1997. Approximately $10 \%$ of the approximately 22,000 victims who gave testimony to the TRC got the chance to testify during these hearings (Harris 2006: 53). The remaining 90\% only testified to the TRC statement-takers. Amnesty hearings were held from May 1996 to December 2000. Other than in exceptional circumstances, all perpetrators testified in public (see TRC Report 1998, Vol. 1: 8). Finally, the TRC also held special hearings from August 1996 to July 1998. During these hearings, the TRC looked into issues such as the armed forces, the business sector, the faith communities and the legal system.

I have only been able to find the term 'restorative justice' in three transcripts of public TRC hearings (one victim hearing and two special hearings). ${ }^{2}$ The first transcript that contains the term 'restorative justice' is from Father Michael Lapsley's testimony during the victim hearings in Kimberley on 10 June 1996. In April 1990, he received a letter bomb believed to have been sent by a government dead squad. During the hearing, he describes the explosion of the bomb:

One of the extraordinary things was that I, and the doctors don't know why, I didn't become unconscious - I didn't go into shock. The ceiling of the rooms blew out and there was a hole in the floor and I can still remember what happened - the actual explosion is still - it's still - it's still something with me. I remember pain of a scale that I didn't think a human being could ever experience. I remember going into darkness - being thrown backwards by the force of the bomb ... I thought maybe it would have been better to have died when I realised I had no hands (TRC victim hearing, Kimberley, 10 June 1996).

After telling his story, Michael Lapsley explained that for him forgiveness was not yet on the agenda. He underscored that the reason for this was not that he was filled with hatred, bitterness, self-pity or a desire for revenge. He said:

I think - I think what I believe in is not retribution, I believe in restorative justice - not retributive justice, restorative justice. And for example - if FW [Frederik Willem de Klerk] was to come to me or the person who made the bomb was to come to me and said I'm sorry for what I did. And I want your forgiveness and this is what I'm now doing in the way of reparation. Not to me personally but to our country and our people, these are the kinds of things I'm

2 The transcripts of the public TRC hearings are uploaded on the TRC website: http://www.justice.gov.za/trc/hrvtrans/index.htm. By means of the search function on this site, it is possible to search for specific terms within the content of all the documents that are uploaded on the site. If one searches for 'restorative justice', one gets a list of all the documents (including all the transcripts of public hearings) that contain the term. 
doing to heal our land then of course one would say of course here is forgiveness, there would be no problem about that. But I haven't heard from De Klerk one word of remorse (TRC victim hearing, Kimberley, 10 June 1996).

Alex Boraine, the vice chairman of the TRC, asked Michael Lapsley to imagine a situation where the people responsible for the bomb made full disclosure and received amnesty. He asked whether that situation 'would meet with your [emphasis mine] restorative justice' (TRC victim hearing, Kimberley, 10 June 1996). Michael Lapsley did not provide a clear answer but stated that:

Well, you see my view has always been that it would be - have been much more desirable for there to be trials and then amnesty ... I believe that we are sacrificing a degree of justice which I think extremely painful to the nation for the sake of the greater good ... if we hadn't had amnesty we were going to have civil war that was going to consume us all (TRC victim hearing, Kimberley, 10 June 1996).

The term 'restorative justice' also appeared during the Faith Community Hearings in East London on 17 November 1997, where the Reverend Wesley Mabuza, the general secretary of the Institute for Contextual Theology (ICT), gave a statement. He explained that, among ICT's members, 'Lack of a mechanism that makes the perpetrators take responsibility for their actions is causing some resentment to say the least' (TRC faith community hearing, East London, 17 November 1997). After the statement, Khoza Mgojo, whom I have already quoted in relation to the Trust Feed Massacre, said:

Would I be right to say that the concern of the Contextual Theology, mostly, related to what is happening now is that you think there is a lack of restorative justice? You have said that even perpetrators, they just go free, having not been asked to do anything. Is that your basis that it lacks, in fact in your very short submission, you have also quoted some of the flaws of the TRC and when a person reads around this, you find that things have been made easy for the perpetrators. Am I right? (TRC faith community hearing, East London, 17 November 1997).

A representative of the ICT, whose name is not recorded in the transcript, said:

What has been coming through is that there is some kind of resentment to the fact that people go away with impunity and people are not calling for the execution of others, they are not calling for the jailing of others, but they are saying some form of mechanism that will show that people are taking responsibility for what they have done would in fact be a step ahead (TRC faith community hearing, East London, 17 November 1997).

Finally, the term 'restorative justice' appears in the transcript of the Legal Hearings in Johannesburg on 27 October 1997. Here Dullah Omar, the Minister of Justice, gave a statement. He said:

[W]hat the Commission has done and the [Reparation and Rehabilitation] Committee has done is to say that we must begin to address issues which affect the fundamental basis of our criminal law from another dimension and that is from the basis of the principle of restorative justice and restitution. What can we do to ensure that victims are placed in a position as best as possible to that before 
the harm was committed? What steps can be taken to restore the dignity of victims? And so those are major questions. Not only for the Commission but for the future of our criminal law in the country (TRC legal hearing, Johannesburg, 27 October 1997).

In the statement, Dullah Omar also explained that he had asked the South African Law Commission 'to review the whole question of victim empowerment'. At the time when Dullah Omar spoke to the TRC, the Law Commission had been working on the issue of victim empowerment for a while and had, already in April 1997, published its Issue Paper 7 entitled 'Sentencing Restorative Justice (Compensation for Victims of Crime and Victim Empowerment)', where RJ is debated.

The Term 'Restorative Justice' in the TRC Report

Volumes 1-5 of the TRC Report were published in October 1998. After the Amnesty Committee had finalized its work, two more volumes were added to the Report in March 2003. Altogether, the TRC Report consists of more than 4,500 pages. The Report contains a six-page section on RJ (Vol. 1: 125-131), and the term 'restorative justice' also appears in a few other passages (Vol. 1: 9 \& 118; Vol. 5: 435 \& 444; Vol. 6: 109). In the section on RJ, it is stated that RJ is a process that - and I quote:

(a) 'seeks to redefine crime: it shifts the primary focus of crime from the breaking of laws or offences against a faceless state to a perception of crime as violations against a human being, as injury or wrong done to another person;

(b) is based on reparation: it aims at the healing and the restoration of all concerned of victims in the first place, but also of offenders, their families and the larger community;

(c) encourages victims, offenders and the community to be directly involved in resolving conflict, with the state and legal professionals acting as facilitators;

(d) supports a criminal system that aims at offender accountability, full participation of both the victims and offenders and making good or putting right what is wrong' (Vol. 1: 126).

The TRC Report refers to Issue Paper 7 from the South African Law Commission as the background to this understanding of RJ (see Vol. 1: 126, note 22).

In the TRC Report, it is stated that ' $\mathrm{r}$ ] estorative justice challenges South Africans to build on the humanitarian and caring ethos of the South African Constitution and to emphasise the need for reparation rather than retaliation - despite growing anger and insecurity in the midst of high levels of crime in South Africa' (Vol. 1: 127). The Report also explains that one of the unique features of the Promotion of National Unity and Reconciliation Act (No. 34 of 1995), which established the TRC, was that it provided guiding principles on how the TRC should deal with victims. The Report states that ' $[\mathrm{t}]$ hese principles constituted the essence of the Commission's commitment to restorative justice' (Vol. 1: 128). In this connection, the Report highlights the principle that the Commission was required to help restore the human and civil dignity of victims 'by granting them an opportunity to relate their own accounts of the violations of which they are the victim' (Vol. 1: 128). Later in the Report, the TRC paints a rather rosy picture of the victim hearings:

The [TRC] process allowed victims to be reintegrated into society. In hearings, victims often approached the Commission almost in a foetal position as they came to take their seats and relate their stories. They told their stories as they 
saw them, as they experienced them, as they perceived what had happened to them. And as they left their seats, the image was wholly different. They walked tall. They were reintegrated into their community. They could re-assume their roles in society; they could manage themselves and the world around them again. They were healthy cells of the national organism. This too is restorative justice. This too is the spirit of ubuntu (Vol. 5: 444).

In relation to the amnesty process, the Report explains that:

[W]e are faced with a paradox: The disclosure of sometimes horrendous deeds, crimes, gross violations of human rights, committed with political motive under an old order, to be followed by a joyous reintegration into society within a new order of the perpetrator of those self-same deeds. This is seeing both the deed and the doer and severing them from each other. This is part of restorative justice. This is part of the spirit of ubuntu. It is part of the restoration of the organism that is our nation South Africa (Vol. 5: 444).

In several passages, the Report touches on the question of whether the amnesty process was just. The TRC makes it clear that amnesty is unjust from a retributive point of view, but argues that the tendency to equate justice with retributive justice must be challenged and RJ considered as an alternative:

Certainly, amnesty cannot be viewed as justice if we think of justice only as retributive and punitive in nature. We believe, however, that there is another kind of justice - a restorative justice which is concerned not so much with punishment as with correcting imbalances, restoring broken relationships - with healing, harmony and reconciliation (Vol. 1: 9).

$[\mathrm{T}]$ he tendency to equate justice with retribution must be challenged and the concept of restorative justice considered as an alternative. This means that amnesty in return for public and full disclosure (as understood within the broader context of the Commission) suggests a restorative understanding of justice, focussing on the healing of victims and perpetrators and on communal restoration (Vol. 1: 118).

However, as noted earlier, the Report also states that '[r]estorative justice demands that the accountability of perpetrators be extended to making a contribution to the restoration of the well-being of their victims' (Vol. 1: 131). This suggests that the South African amnesty process was not an ideal example of RJ, since perpetrators were not required to do anything for their victims.

Some Reflections on the Appearance of the Term 'Restorative Justice' in the Public TRC Hearings and the TRC Report

RJ does not seem to have been an issue of much debate during the day-to-day proceedings of the TRC. As explained, my research shows that the term 'restorative justice' appeared only in three public TRC hearings, which is a tiny minority of the large number of hearings. It should also be noted that the term 'restorative justice' does not appear in the legal documents that form the background to the TRC. The Interim Constitution (Act 200 of 1993), which adjudicated that there should be amnesty after apartheid, does not contain the term 'restorative justice', and neither does the Promotion of National Unity and Reconciliation Act (No. 34 of 1995), which established the TRC 
and defined its mandate. Against this background, it may be surprising that the TRC Report depict the TRC as an institution that attempted to promote RJ.

I have found no evidence that the TRC considered itself as an institution committed to RJ when it began to conduct public hearings in April 1996. As pointed out above, my hypothesis is that the TRC first really began to take notice of the term 'restorative justice' after the South African Law Commission had published Issue Paper 7 in April 1997. This publication was important in bringing RJ onto the legal agenda in South Africa. In fact, the term 'restorative justice' did not appear in any South African legal documents before this publication. Since publication of the issue paper, however, the term has appeared in 4 Acts, 27 judgements by High Courts, 15 judgements by the Constitutional Court, 8 judgements by the Supreme Court of Appeal, and one judgement each by the Equality Court and the Land Claims Court. ${ }^{3}$ The TRC Report does, as I have noted, refer to Issue Paper 7 as the background to its understanding of RJ, and I find it likely that it was this issue paper (maybe in combination with Dullah Omar's reference to the Law Commission's work when he testified to the TRC on 27 October 1997) that made the TRC aware that the idea of RJ could be used to explain its work. If this is true, then the TRC Report's description of the TRC as an institution committed to RJ represents, to a considerable extent, a retrospective self-interpretation.

\section{Africanizing Restorative Justice}

I will now turn to investigate the argument that RJ has deep historical roots in African indigenous cultures through its close congruity with ubuntu and AIJS. If it could be shown that RJ has deep historical roots in African cultures this would have legitimizing effects on RJ among those calling for Africanization. In this connection, it should be noted that there is a tendency for formerly suppressed African peoples to call for Africanization when they gain political power. This was already evident during the early years of decolonization. As explained by Julius Nyerere, throughout nearly the whole of Africa 'the first and most vocal demand of the people after independence was for Africanization' (Nyerere 1968: 27).

In South Africa, the call for Africanization was already evident during apartheid, for instance in the Black Consciousness movement. Steve Biko, who led the movement prior to his death at the hands of the apartheid regime, explained that '[s]ince that unfortunate date - 1652 - we have been experiencing a process of acculturation' (Biko 1978: 40). Therefore, he states, 'part of the approach envisaged in bringing about "black consciousness" has to be directed to the past, to seek to rewrite the history of the black man and to produce in it the heroes who form the core of the African background' (Biko 1978: 29). It is, as he notes, 'through the evolution of our genuine culture that our identity can be fully rediscovered' (Biko 1978: 71).

After the transition to multi-racial democracy in South Africa, the idea of Africanization was emphasized in the call for an African Renaissance (i.e. 'African

3 My search for South African legal documents that contain the term 'restorative justice' was conducted on 31 August 2012. A list of the relevant documents can be generated in the following way: go to the website of Southern African Legal Information Institute (www.saflii.org); choose 'South Africa' under 'Browse by Country'; search for 'restorative justice'; choose to categorize the documents 'By Database'. 
re-birth'). The term 'African Renaissance' was popularized by Thabo Mbeki. ${ }^{4}$ In his speech at the United Nations University on 9 April 1998, entitled 'The African Renaissance, South Africa and the World', Thabo Mbeki said that: 'I would dare say that confidence [among Africans], in part, derives from a rediscovery of ourselves, from the fact that, perforce, as one would who is critical of oneself, we have had to undertake a voyage of discovery into our antecedents, our own past, as Africans'. In 'The African Renaissance Statement' of 13 August 1998, Thabo Mbeki also explained that: 'To perpetuate their imperial domination over the peoples of Africa, the colonisers sought to enslave the African mind and to destroy the African soul'. He added that therefore, '[t]he beginning of our rebirth as a Continent must be our own rediscovery of our soul'.

In the following, I will show that even though it has been common to argue that RJ has deep historical roots in African indigenous cultures through its congruence with ubuntu and AIJS, the connection between RJ and ubuntu, like that between RJ and AIJS, is less straightforward and unproblematic than often assumed.

\section{$R J$ and Ubuntu}

According to the South African Constitutional Court, the spirit of ubuntu is something that is 'part of the deep cultural heritage of the majority of the population' (Port Elizabeth Municipality v Various Occupiers, 2005: § 37). The Constitutional Court also explains that '[t]he spirit of ubuntu, part of the deep cultural heritage of the majority of the population, suffuses the whole constitutional order' (Port Elizabeth Municipality v Various Occupiers, 2004: §37). The idea that ubuntu suffuses the constitutional order is founded on the statement in the Epilogue of the Interim Constitution that, in addressing the divisions and strife of the apartheid era, there is 'a need for ubuntu' (Constitution of the Republic of South Africa, Act 200 of 1993: Epilogue after Section 251).

In post-apartheid South Africa, it has been argued that RJ, in contrast to retributive justice, is congruent with ubuntu. This view has, for instance, been presented by the Constitutional Court, which has stated that ' $[r]$ estorative justice, in our jurisprudence, is linked to the foundational value or norm of Ubuntu-Botho [the Setswana term 'botho' is often used synonymously with the Nguni term 'ubuntu']' (Van Vure v Minister of Correctional Services and Others, 2010: § 51). In the Constitutional Court case Dikoko v Mokhatla of 2006, it is also explained that 'Ubuntu-botho is highly consonant with rapidly evolving international notions of restorative justice' (§ 114) and that 'courts need to explore the wide and creative possibility afforded by restorative justice as contemplated by the indigenous values of ubuntu or botho' (\$ 36).

My research suggests that the idea that there is a connection between RJ and ubuntu is of recent origin. In fact, I have not been able to find any texts that present this idea prior to 1997. To my knowledge, Eric K. Yamamoto, a professor of law and social jus-

4 It was not Thabo Mbeki who coined the term 'African renaissance'. The oldest text, in which I have found the term, is Edwin William Smith's The Way of White Fields: A Survey of Christian Enterprise in Northern and Southern Rhodesia from 1928. In this book, there is a section entitled 'The Era of African Renaissance', which primarily consists of a long quote from Reverend John White's address at the Southern Rhodesia Missionary Conference in August 1926. Part of this quote reads: 'Since I set foot in Africa over thirty years ago a profound change has taken place in the entire outlook of the native people of this sub-continent. Through the public press and by various other authorities we are being constantly reminded of what is called the dawning Bantu race-consciousness; of his restlessness, under white dominion; of his dissatisfaction with his social, industrial and political status. To those who look below the surface these things are the symptoms of a profound psychological revolution that is silently, slowly but surely, going on. In short we are witnessing a nation in its birth-throes' (Smith 1928: 142). 
tice at the University of Hawaii, may have been the first author to connect RJ and ubuntu when he wrote as follows in an article section on the South African TRC:

[R]estorative justice is reflective of the African notion of ' $u b u n t u$ ', or interconnectedness. Ubuntu is the idea that no one can be healthy when the community is sick. 'Ubuntu says I am human only because you are human. If I undermine your humanity, I dehumanise myself.' It characterizes justice as community restoration - the rebuilding of the community to include those harmed or formerly excluded (Yamamoto 1997: 52).

Since 1997 it has become common for South African scholars to associate RJ and ubuntu. RJ and ubuntu have, for instance, been connected by Ann Skelton and Cheryl Frank in a passage where they argue that while the term 'restorative justice' may be relatively new to South Africans, the spirit of RJ is not:

At the outset, it is important to establish that while the term restorative justice may be relatively new to South Africans, the spirit of the concept is strongly embedded in the history of African society through the notion of ubuntu. Mokgoro (in Boraine 2000) describes ubuntu as an African worldview, which is both a guide for social conduct as well as a philosophy of life. Therefore, more than merely applicable to issues of justice, ubuntu describes the individual's status in relation to others through the idea that a person is only a person because of other people. Ubuntu embodies ideas about the interconnectedness of people to each other, the importance of the family group over the individual, and the value of benevolence towards all others in the community (Skelton \& Frank 2001: 104).

The idea that there is a congruence between RJ and ubuntu is also presented in the TRC Report in the section entitled 'Ubuntu: Promoting Restorative Justice' (TRC Report 1998, Vol. 1: 125-131). The TRC does not go into much detail on how RJ and ubuntu are connected, but the quotation below suggests that RJ and ubuntu are somehow bound together by the constitutional commitment to 'a need for understanding but not for vengeance, a need for reparation but not for retaliation, a need for ubuntu but not for victimisation' (Constitution of the Republic of South Africa, Act 200 of 1993: Epilogue after Section 251):

In the words of Constitutional Court Judge O'Regan: 'Apartheid was a denial of a common humanity. Black people were refused respect and dignity and thereby the dignity of all South Africans was diminished. The new Constitution rejects this past and affirms the equal worth of all South Africans. Thus recognition and protection of human dignity is the touchstone of the new political order and is fundamental to the new Constitution'. This was the background to the constitutional commitment to 'a need for understanding but not for vengeance, a need for reparation but not for retaliation, a need for ubuntu but not for victimisation'. It was a commitment that called for a respect for human life and dignity and for a revival of ubuntu; a commitment that included the strengthening of the restorative dimensions of justice (TRC Report 1998, Vol. 1: 126).

There does not seem to be any consensus on how exactly the connection between RJ and ubuntu is constituted. This may not come as a surprise, for in the absence of any 
consensus on the nature of either RJ or ubuntu, it makes good sense that there is no consensus on the relation between the two. I have explored a number of different views on what ubuntu is in my two articles, 'The Historical Development of the Written Discourses on Ubuntu' (Gade 2011) and 'What is Ubuntu? Different Interpretations among South Africans of African Descent' (Gade 2012). In the first of these, I investigate how ubuntu has been defined in written sources since 1846 and show that new definitions have emerged at different points in history. In the second article, I describe and systematize the many different answers to the question 'What is ubuntu?' that I have been able to identify among South Africans of African descent.

$R J$ and African Indigenous Justice Systems (AIJS)

When the Europeans arrived in present-day South Africa, justice among the African peoples was administrated by indigenous justice systems. Later, the authority of these justice systems was restricted by South Africans of European descent. Under the Native Administration Act (No. 38 of 1927) approved chiefs or headmen were allowed to decide in legal cases among 'blacks' according to custom, but all major offences, such as murder, had to be tried in the magistrates' courts or in the Supreme Court. In post-apartheid South Africa, traditional leadership was an issue in the Interim Constitution of 1993 (Chapter 11) and also in the final Constitution of 1996 (Chapter 12). Later, in 2003, matters concerning traditional leadership were subjected to the Traditional Leadership and Governance Framework Act (No. 41 of 2003). However, neither of the two post-apartheid constitutions, nor the Traditional Leadership and Governance Framework Act, touches on the subject of traditional courts. This subject is dealt with in the Traditional Courts Bill of 2008. Concerning the nature of traditional courts, the Bill explains that:

Traditional courts are distinct from courts referred to in section 166 of the Constitution [the Constitutional Court, the Supreme Court of Appeal, the High Courts and the magistrates' courts], and operate in accordance with a system of customary law and custom that seeks to - (a) prevent conflict; (b) maintain harmony; and (c) resolve disputes where they have occurred, in a manner that promotes restorative justice [emphasis mine] and reconciliation and in accordance with the norms and standards reflected in the Constitution (Traditional Courts Bill, 2008: § 7).

In post-apartheid South Africa, it has been argued that RJ is in harmony with AIJS, not only in their present forms, but also as they were constituted before their subjection to external regulations. As cited above, Desmond Tutu writes, for instance, that RJ was characteristic of traditional African jurisprudence (Tutu 1999: 51), and in an article on RJ, Ann Skelton and Cheryl Frank state that 'as far back as oral history can take us, African communities have seen justice through a restorative lens' (Skelton \& Frank 2001: 104). The South African Constitutional Court also claims that ' $[\mathrm{t}]$ hese concepts [of RJ] harmonise with processes well-known to traditional forms of dispute resolution in our country, processes that have long been, and continue to be, underpinned by the philosophy of ubuntu-botho' (Dikoko v Mokhatla, 2006: 114).

It is a common view in the literature that AIJS have always focussed on restoration rather than retribution. This view is, for instance, put forward in Timothy Murithi's article, 'Practical Peacemaking Wisdom from Africa: Reflections on Ubuntu' (2006). Here it is stated that 'Ubuntu societies [it is not explained what this means] maintained conflict resolution and reconciliation mechanisms which also served as institutions for 
maintaining law and order within society' (Murithi 2006: 29). Timothy Murithi writes that in the context of the ubuntu societies found in southern Africa disputes would be resolved through an institution known as the inkundla/legotla, which served as a group mediation and reconciliation forum. He underscores that this forum was communal in character: the entire society was involved at various levels in trying to find a solution to the problem that was brought before the forum. Furthermore, he explains that after the perpetrator had paid an appropriate compensation for the wrong done, '[a]mnesty could thus be granted, but not with impunity' (Murithi 2006: 31). He also emphasizes that:

In the more difficult cases involving murder, Ubuntu societies sought to avoid the death penalty because, based on the society's view of itself - as people through other people - the death penalty would only serve to cause injury to the society as a whole. Though it would be more difficult to move beyond such cases, the emphasis would still be on restoring the broken relationships caused by the death of a member of the community (Murithi 2006: 31).

In another article discussing the constitution of the inkundla/lekgotla, Nomonde Masina claims that the death penalty was rare in former times. Based on his article, it seems that the death penalty was not imposed in cases of murder, theft or incest (Masina 2000). Only witchcraft is mentioned as incurring the death penalty, and Nomonde Masina explains that 'capital punishment was imposed in cases of witchcraft because a witch was feared to be a menace to society' (Masina 2000: 175). The Constitutional Court Case $S$ v Makwanyane and Another of 1995, which declared the death penalty unconstitutional and forbade the execution of the more than 300 people on the South African death row (see $\S 6 \& \S 151$ ), also touches on the issue of AIJS. In the judgement, Justice Albie Sachs explains that:

[I]f these sources are reliable [see $\S 377$ ], it would appear that the relatively well-developed judicial processes of indigenous societies did not in general encompass capital punishment for murder. Such executions as took place were the frenzied, extrajudicial killings of supposed witches, a spontaneous and irrational form of crowd behaviour that has unfortunately continued to this day in the form of necklacing and witch-burning. In addition, punishments by military leaders in terms of military discipline were frequently of the harshest kind and accounted for the lives of many persons. Yet, the sources referred to above indicate that, where judicial procedures were followed, capital punishment was in general not applied as a punishment for murder ( $S v$ Makwanyane and Another, 1995: § 381).

Is RJ really in harmony with AIJS? RJ may be is in harmony with AIJS in their present South African forms, but it is questionable whether RJ can reasonably be said to be in harmony with AIJS of former times if these justice systems were putting assumed witches to death, as is stated in many sources (see e.g. Maclean 1858: 85 \& 126; Commission on Laws and Customs of the Basutos 1873: 51; Junod 1913: 417; Strayt 1931: 223; Cook 1931: 153; Krige 1936: 219 \& 225-227; Schapera 1938: 276). Furthermore, the harmony of former times between RJ and AIJS becomes even more dubious if not only assumed witches, but also perpetrators of other types of crimes, such as murder, theft and incest, sometimes received the death penalty. Some nineteenth- and early 
twentieth-century texts claim that the death penalty was used in such cases, as will be shown below.

Example I (murder). On 4 December 1872, the Commission on Native Laws and Customs of the Basutos interviewed Sofonia Moshesh, who had been working in the court of the late Chief Moshesh. Asked about the Basutu law with regard to wilful murder, Sofonia Moshesh replied that there was no fixed law on the subject: 'each chief decides the case brought before him as he thinks fit'; however: '[t]he usual punishment for killing another person is a fine of cattle' (Commission on Laws and Customs of the Basutos 1873: $46 \& 47)$. Sofinia Moshesh added that:

I have heard of some cases in which the murderer has been put to death, but [the late Chief] Moshesh did not approve of this punishment, because the person or persons who put the murderer to death became murderers themselves by doing so. I only know of my own knowledge of one case in which Moshesh had a murderer put to death (Commission on Laws and Customs of the Basutos 1873: 47).

Henri Junod explains that among the Thonga in former times '[i]f the murder is deliberate, it is punished by death' (Junod 1913: 415). Similarly, it has been argued that among the Bapedi the punishment for murder was death (Harries 1929: 101) and among the Bavenda death or banishment (Strayt 1931: 223). P. A. W. Cook also explains that among the Bomvana, the lex talionis principle applied if a murderer was caught by the people just after the killing (Cook 1931: 152). C. L. Harries even claims that when Bapedi 'native doctors' had smelled out a murderer:

[T]he chief would summon his young warriors and charge them with the murderous duty of annihilating the whole family to which the alleged murderer belonged. The reason why such drastic penalties were meted out was that the murderer's family must have known that one of its members was guilty (Harries 1929: 102).

Isaac Schapera writes as follows about the punishment for murder among the Tswana:

In the olden days all such cases [of homicide] could be tried by him [the chief], and not by any of the minor courts. Culpable homicide and murder were punished by death. The murderer was escorted to the top of a large rock outside the village, and there either stabbed with a spear or hit on the head with a club, according to the manner in which he had killed his victim (Schapera 1938: 261).

Example II (theft). On 3 December 1872, the Commission on Native Laws and Customs of the Basutos conducted an interview with George Tladi Moshesh, son of the late Chief Moshesh. Questioned about the punishment of theft, he answered that:

This crime is punished by fine; but in the case of notorious thieves, who are likely to involve the country in war by stealing from neighbouring nations, they are sometimes put to death. I knew of four notorious thieves who were put to death by order of my father Moshesh. If a thief is found at night in the act of breaking open or stealing out of the kraal, he can be shot or stabbed with an assegai, without the person killing or wounding him being subjected to any punishment or blame (Commission on Laws and Customs of the Basutos 1873: 44). 
Sofinia Moshesh gave a similar answer when interviewed by the commission, and added that the Basutos have a proverb saying that 'A thief is a dog which must pay with its head' (Commission on Laws and Customs of the Basutos 1873). Isaac Schapera also explains that, among the Tswana,

Theft, particularly livestock, was formerly punished very severely. A thief found in the veld with stolen cattle in his possession was often killed on the spot, or very severely trashed, or tortured by having his hands burned. Nowadays he must be brought to the kgotla for trial; and it is still not unusual for him to be severely trashed by order of the Chief, particularly if he has no property of his own which can be taken from him. The general rule, however, in cases of theft is that the owner of the stolen property is entitled to receive twice the value of the article stolen (Schapera 1938: 271)

Example III (incest). Hugh A. Strayt claims that, among the Bavenda,

Incest is a serious crime; the offender is considered to be a dog and is the subject of horror and scorn. He is tried in the chief's court and is punished by death or banishment. Perverse sexual aberrations are similarly punished (Strayt 1931: 224).

Eileen Jensen Krige explains that among the Zulus, the reaction of society to incest varies according to how closely the people concerned are related. If a man commits incest with his own sister, or with a young wife of his father,

The father himself, assisted by the kin of the village, would put 'the dog' to death for having thus shamed them. If, however, the relationship is less close and a relative such as the father's sister's child is married, people will be angry and the culprit might be forced to flee from public opinion, but he would not be put to death. It is believed, however, that the ancestral spirits themselves will inflict punishment, and that the offspring of an incestuous relationship will be a monster (Krige 1936: 224).

\section{Final Remarks}

In this article, I have attempted to open up new discussions of RJ and the TRC process by showing that the term 'restorative justice' appears only in transcripts of three public TRC hearings, and that the TRC might not have taken significant notice of the term before the publication of Issue Paper 7 by the South African Law Commission.

When the TRC wrote its Report, it was faced with the challenge of explaining why justice was not sacrificed when amnesty was offered to apartheid perpetrators. In this connection the term 'restorative justice' became useful, since it could be applied to argue that even though the TRC did not promote retributive justice, it did promote another kind of justice, namely RJ. I take no stance here on whether the TRC used the term 'restorative justice' for merely strategic reasons. It might be the case that when the Report was written, many people working on the TRC were of the view that the Commission was committed to RJ. Furthermore, it might be the case that the work of the TRC was fully or partially congruent with RJ, even if the TRC had taken no significant notice of the term 'restorative justice' in the beginning of the TRC process.

Concerning the attempts to Africanize RJ, I want to mention that at least in some ways it would make sense to claim that RJ is something Western: as I have shown, the term 'restorative justice' first appeared in nineteenth-century works by Western au- 
thors, and Albert Eglash, Randy Barnett, Nils Christie and Howard Zehr, sometimes considered as founding fathers of RJ, all came from Europe or the US. To my knowledge, the term 'restorative justice' did not enter the writing of African scholars or the discussions of African politicians before the 1990s.

To rule out misunderstandings, I want to emphasize that I am not arguing that there is no congruence between RJ and ubuntu. My point is simply that the idea of such congruence was formulated in writing very recently, and also that there is no consensus on how the connection between RJ and ubuntu is constituted. Furthermore, I wish to underscore that I am not denying that the traditional courts of present-day South Africa might operate in conformity with RJ. I do, however, find it more dubious whether AIJS of former times were in harmony with RJ. Many present scholars seem to over-romanticize AIJS of former times. As some scholars have pointed out, there is often a tendency to over-romanticize the past and idealize traditional cultures (Keeley 1996; Sandall 2001). However, it should not be forgotten that the nineteenth- and early twentieth-century texts on AIJS were written in a colonial context, where there might have been a tendency to paint an over-negative picture of African culture. In this connection, I will give Steve Biko the last word:

[T]he colonialists were not satisfied merely with holding a people in their grip and emptying the Native's brain of all form and content, they turned to the past of the oppressed people and distorted, disfigured and destroyed it. No longer was reference made to African culture, it became barbarism. Africa was the 'dark continent'. Religious practices and customs were referred to as superstition. The history of African Society was reduced to tribal battles and internecine wars. There was no conscious migration by the people from one place of abode to another. No, it was always flight from one tyrant who wanted to defeat the tribe not for any positive reasons but merely to wipe them out of the face of the earth (Biko 1978: 29).

\section{References}

Abbots, B. 1863. A Woman's Story. Vol. 2. London: T. Cautley Newby.

Allena, T. 2004. 'Restorative Conferences: Developing Students Responsibility by Repairing the Harm to Victims and Restoring the University Community', in: Karp, D.R. \& Allena, T. (eds.). Restorative Justice on the College Campus: Promoting Student Growth and Responsibility, and Reawakening the Spirit of Campus Community. Illinois: Charles C. Thomas.

Ammar, N.H. 2003. 'Exploring Elements of Restorative Justice in the Islamic Legal System', in: Safty, A. (ed.). Value Leadership and Capacity Building. Boca Raton: Universal Publishers.

Armour, M.P. \& Umbreit, M.S. 2011. 'Restorative Justice and Juvenile Offenders', in: Springer, D.W. \& Roberts, A.R. (eds.). Juvenile Justice and Delinquency. Sudbury: Jones and Bartlett Publishers. 
Armstrong, L. 1848. The Signs of the Times; Comprised in Ten Lectures, Designed to Show the Origin, Nature, Tendency, and Alliances of the Present Popular Efforts for the Abolition of Capital Punishment. New York: Robert Carter.

Barnett, R.E. 1977. 'Restitution: A New Paradigm of Criminal Justice', Ethics 87(4), 279-301.

Bell, R.H. 2002. Understanding African Philosophy: A Cross-Cultural Approach to Classical and Contemporary Issues. New York: Routledge.

Biko, S. 1978. I Write What I Like. San Francisco: Harper \& Row.

Boraine, A. 2000. A Country Unmasked. Oxford: Oxford University Press.

Braithwaite, J. \& Strang, H. 2002. 'Restorative Justice and Family Violence', in: Strang, H. \& Braithwaite, J. (eds). Restorative Justice and Family Violence. Cambridge: Cambridge University Press.

Braithwaite, J. 1998. 'Restorative Justice', in: Tonry, M. (ed.). The Handbook of Crime \& Punishment. Oxford: Oxford University Press.

Burkhead, M.D. 2009. A Life for a Life: The American Debate Over the Death Penalty. North Carolina: McFarland \& Company, Inc., Publishers.

Chatterjee, J. \& Elliott, L. 2003. 'Restorative Policing in Canada: The Royal Canadian Mounted Police, Community Justice Forums, and the Youth Criminal Justice Act', Police Practice and Research: An International Journal 4(4), 347-359.

Christie, N. 1977. 'Conflicts as Property', The British Journal of Criminology 17(1), $1-15$.

Christie, N. 2005. 'Restorative and Retributive Justice in the Context of War and War Crimes', Temida 8(4), 27-32.

Christie, N. 2010. 'Victim Movements at a Crossroad', Punishment \& Society 12(2), $115-122$.

Commission on Laws and Customs of the Basutos 1873. Report and Evidence of Commission on Native Laws and Customs of the Basutos. Cape Town: Saul Solomon \& Co.

Constitution of the Republic of South Africa, Act 200 of 1993.

Constitution of the Republic of South Africa, Act 108 of 1996.

Cook, P.A.W. 1931. Social Organisation and Ceremonial Institutions of the Bomvana. Cape Town: Juta \& Co.

Daly, K. 2013. 'The Punishment Debate in Restorative Justice', in: Simon, J. \& Sparks, R. (eds.). The SAGE Handbook of Punishment and Society. London: Sage Publication.

Dikoko v Mokhatla (CCT62/05) [2006] ZACC 10; 2006 (6) SA 235 (CC); 2007 (1) BCLR 1 (CC) (3 August 2006).

Dorpat, T.L. 2007. Crimes of Punishment: America's Culture of Violence. New York: Algora Publishing. 
Eglash, A. 1957a. 'Creative Restitution: A Broader Meaning for an Old Term', Journal of Criminal Law, Criminology and Police Science 48(6), 619-622.

Eglash, A. 1957b. 'Creative Restitution: Some Suggestions for Prison Rehabilitation Programs', American Journal of Corrections 20, 20-34.

Eglash, A. 1959. 'Creative Restitution: Its Roots in Psychiatry, Religion and Law', British Journal of Delinquency 10, 114-119.

Eglash, A. 1977. 'Beyond Restitution: Creative Restitution', in: Hudson, J. \& Galaway, B. (eds.). Restitution in Criminal Justice: A Critical Assessment of Sanctions. Lexington: Lexington Books.

Fourcade, M. 1924. 'Address of Mr. Manuel Fourcade, Bâtonnier of the Order of Advocates, Etc.', American Bar Association Journal 11, 768-769.

Gade 2011. 'The Historical Development of the Written Discourses on Ubuntu', South African Journal of Philosophy 30(3), 303-329.

Gade 2012. 'What is Ubuntu? Different Interpretations among South Africans of African Descent', South African Journal of Philosophy 31(3), 484-503.

Groothues, C. 2012. 'The Developing Character of Restorative Jusitce', Resolution 44, 22-23.

Harries, C.L. 1929. The Laws and Customs of the Bapedi and Cognate Tribes of the Transvaal. Johannesburg: Hortors Limited.

Harris, V. 2006. 'The TRC's Unfinished Business: Archives', in: Villa-Vicencio, C. \& Du Toit, F. (eds.). Truth \& Reconciliation in South Africa: 10 Years On. Claremont: New Africa Books.

Heath-Thornton, D. 2009. 'Restorative Justice', in: Wilson, J.K. (ed.). The Praeger Handbook of Victimology. Santa Barbara: ABC-CLIO.

Johnstone, J. 2008. 'The Agendas of the Restorative Justice Movement', in: Miller, H.V. (ed.). Restorative Justice: From Theory to Practice. Bringley: Emerald Group Publishing.

Junod, H.A. 1913. The Life of a South African Tribe. Vol. 1. London: Macmillan and Co.

Keeley, L.H. 1996. War Before Civilization: The Myth of the Peaceful Savage. Oxford: Oxford University Press.

Krige, E.J. 1936. The Social System of the Zulus. London: Longmans, Green and Co.

Leonhard, L. \& Kenny, P. 2010. Sustainable Justice and the Community. Bingley: Emerald.

Llewellyn, J.J. \& Howse, R. 1999. Restorative Justice - A Conceptual Framework. Ottawa: Law Commission of Canada.

Maclean, J. 1858. A Compendium of Kafir Laws and Customs. London: Frank Cass \& Co.

Marshall, C. 2011. 'Justice, Restorative', in: Green, J.B. (ed.). Dictionary of Scripture and Ethics. Grand Rapids: Baker Academics. 
Marshall, T.F. 1996. 'The Evolution of Restorative Justice in Britain', European Journal of Criminal Policy and Research 4(4), 21-43.

Marshall, T.F. 1999. Restorative Justice: An Overview. London: Home Office Research Development and Statistics Directorate.

Masina, N. 2000. 'Xhosa Practices of Ubuntu for South Africa', in: Zartman, I.W. (ed.). Traditional Cures for Modern Conflicts: African Conflict "Medicine". London: Lynne Rienner Publishers.

Mbeki, T. 1998. 'The African Renaissance, South Africa and the World'. Speech at the United Nations University on 9 April 1998.

Mbeki, T. 1998. 'The African Renaissance Statement'. Speech at the Gallagher Estate on 13 August 1998.

Mechem, F.R. 1916. 'An Inquiry Concerning Justice', Michigan Law Review 14(5), 361-382.

Members of the Church of Ireland 1834. 'View of Public Affairs for the Year 1834', Christian Examiner and Church of Ireland Magazine 3(27), 1-11.

Murithi, T. 2006. 'Practical Peacemaking Wisdom from Africa: Reflections on Ubuntu', The Journal of Pan African Studies 1(4), 25-34.

Native Administration Act, No. 38 of 1927.

Nyerere, J. K. 1968. Freedom and Socialism. Dar es Salaam: Oxford University Press.

Olson-Burchanan, J.B. \& Boswell, W.R. 2009. Mistreatment in the Workplace: Prevention and Resolution for Managers and Organizations. Malden: Blackwell Publishers.

Port Elizabeth Municipality v Various Occupiers (CCT 53/03) [2004] ZACC 7; 2005

(1) SA 217 (CC); 2004 (12) BCLR 1268 (CC) (1 October 2004).

Pressler, S., Saner, J.S. \& Wasserfall, I. 2009. Criminal Justice Structure and Mandates. FET College Series, L3. Cape Town: Pearson Education South Africa.

Promotion of National Unity and Reconciliation Act, No. 34 of 1995.

S v Makwanyane and Another (CCT3/94) [1995] ZACC 3; 1995 (6) BCLR 665; 1995 (3) SA 391; [1996] 2 CHRLD 164; 1995 (2) SACR 1 (6 June 1995).

Sandall, R. 2001. The Culture Cult. Colorado: Westview Press.

Schapera, I. 1938. A Handbook of Tswana Law and Custom. London: Oxford University Press.

Skelton, A. \& Frank, C. 2001. 'Conferencing in South Africa: Returning to Our Future', in: Morris, A. \& Maxwell, G. (eds.). Oxford: Hart Publishing.

Smith, E.W. 1928. The Way of the White Fields in Rhodesia. London: World Dominion Press.

South African Law Commission 1997. Sentencing Restorative Justice (Compensation for Victims of Crime and Victim Empowerment). Issue Paper 7, Project 82. 
Stamatakis, N. \& Beken, T.V. 2010. 'Myths and Reality in the History of Restorative Justice', in: Cools, M. et al. (eds.). Safety, Societal Problems and Citizen's Perceptions. Antwerpen: Maklu.

Stow, J. 1856. Thoughts on a Continuation of the Book of Common Prayer Used in the Church of England. London: Printed at the School-Press.

Strayt, H.A. 1931. The Bavenda. London: Oxford University Press.

Strickland, R.A. 2004. Restorative Justice. New York: Peter Lang Publishing.

Traditional Court Bill, 2008.

Traditional Leadership and Governance Framework Act, No. 41 of 2003.

Truth and Reconciliation Commission of South Africa 1998. Truth and Reconciliation Commission of South Africa Report. Vol. 1-5. Cape Town: Juta.

Truth and Reconciliation Commission of South Africa 2003. Truth and Reconciliation Commission of South Africa Report. Vol. 6-7. Cape Town: Juta.

Tutu, D. 1999. No Future Without Forgiveness. London: Rider.

United Nations Office of Drugs and Crime. 2006. Handbook on Restorative Justice Programmes. New York: United Nations.

Van Ness, D.W. 1993. 'New Wine and Old Wineskins: Four Challenges of Restorative Justice', Criminal Law Forum 4(2), 251-276.

Van Ness, D.W. 2005. 'An Overview of Restorative Justice Around the World'. Address delivered at the Eleventh United Nations Congress on Crime Prevention and Criminal Justice in Bangkok.

Van Ness, D.W. \& Strong, K.H. 2010. Restoring Justice: An Introduction to Restorative Justice. $4^{\text {th }}$ ed. New Jersey: LexisNexis.

Van Wormer, K. 2003. 'Restorative Justice: A Model for Social Work with Families', Families in Societies: The Journal of Contemporary Human Services 84(3), 441-448.

Van Vuren v Minister of Correctional Services and Others (CCT 07/10) [2010] ZACC 17; 2010 (12) BCLR 1233 (CC); 2012 (1) SACR 103 (CC) (30 September 2010).

Weitekamp, E.G.M. 1999. 'The History of Restorative Justice', in: Balzemore, G. \& Walgrave, L. (eds.). Restorative Juvenile Justice: Repairing the Harm of Youth Crime. New York: Criminal Justice Press.

Yamamoto, E.K. 1997. 'Race Apologies', Journal of Gender, Race and Justice 1, $47-88$.

Zedner, L. 2006. 'Punishment and the Plurality of Privacy Interests', in: Claes, E., Duff, A. \& Gutwirth, S. (eds.). Privacy and the Criminal Law. Antwerpen: Intersentia.

Zehr, H. 1985. 'Retributive Justice, Restorative Justice', New Perspectives on Crime and Justice 4.

Zehr, H. 1990. Changing Lenses: A New Focus for Crime and Justice. Scottdale, PA: Herald Press. 
Zehr, H. 2002. The Little Book of Restorative Justice. Intercourse, PA: Good Books. 